\title{
"A STORY OF "BAQAROH": A JUSTIFICATION \\ OF THE ISRAILIAN ANOMALY AND \\ DISOBIDIANCE'
}

\author{
Afrizal Nur \\ Dosen Program Pasca Sarjana UIN Suska Riau
}

\begin{abstract}
The Qur'anis a reference for human beings to see the history of human civilization in ancient time, including the history ofthe Jewish people. The Jews have atradition of badfaith always deviate from "Tauhid" (monotheism), this condition is common and has become a habitthathas taken holdofmany generations. Practices ofidolatry, paganism, anomaly form sand other disobediences, which is a tradition that regenerates and will continue inhibit to the Jews. Bani Israil also did not obey to the treatise which brought the prophet Moses. Deviating conception (anomalous), their bad qualities such as hostile, stubborn, hard-hearted, broken promises, grabber, greedy and others, have repeatedly told by God in the Qur'an. Message from surah al-Baqarah verse 67 is the evidence that justifies how bad character of Bani Israil. Philosopher Karl Marx said: "The Jew can only be free when their habitual attitude
\end{abstract}

Keywords :Bani Israil, TheJews; anomaly ; disobediences

\section{Pendahuluan}

Nabi Musa a.s sangat mencintai kaumnya Bani Isra'il, meskipun kederhakaan Bani Isra'il kepadanya kerap kali dilakukan, namun tetap sahaja beliau (nabi Musa a.s) mengasihi dan mencintai kaumnya. Kabar akan kedatangan nabi Muhammad saw sebagi pembawa risalah terakhir pun ditentang orang-orang Yahudi, bahkan dibanyak ayat, Allah SWT selalu menyebutkan mereka sebagai orang-orang yang berbuat dzalim, sebagaimana pada ayat 5 surah al-Jummuah : 


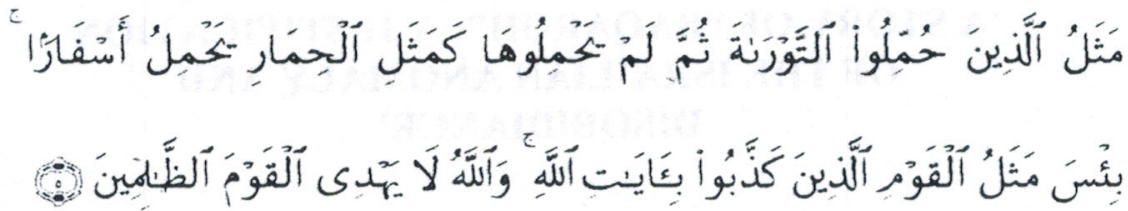

Maksudnya :

Perumpamaan orang-orang yang dipikulkan kepadanya Taurat,

Kemudian mereka tiada memikulnya adalah seperti keledai yang membawa kitah-kitah vang tebal.Amatlah buruknya perumpamaan kaum lang mendustakan arat-asat. Hah itudan. Hllah tiada memberi petunjuk kepada kaum yang zalim.

Dari ayat tersebut dapat kita pahami bahawaorang dzalim tidak akan diberikan Allah SWT hidayah kerana mereka tersebut adalah dari kelompok orang-orang Yahudi dan Nasrani. Allah memberikan perumpamaan kepada orang-orang Yahudi yang telah diberikan Taurat supaya mereka mengamalkan isi kandungan nya, namun kenyataannya mereka tidak mengamalkannya dan tidak menjadikannya sebagai petunjuk hidup atau memperoleh hidayah dan penerang dari nya. Allah membuat perumpamaan seperti haiwan bernama "keledai" yang membawa banyak kitab, namun mereka tidak mendapatkan manfaat dari kitab-kitab yang dibawanya tersebut, melainkan keletihan dan kepenatan sahaja. AlBaidhawi menyebutkan "Allah telah mencelah mereka (Yahudi) karena mereka adalah para pembaca kitab, pakar, dan didalamnya terdapat informasi tentang kenabian Muhammad saw dan kewajiban beriman kepadanya, akan tetapi mereka tidak memetik manfaat dari nya dan dari kesengsaraannya dahulu yang mereka alami. Inilah seburuk-buruk perumpamaan yang dikemukakan Allah karena Yahudi adalah kaum "pendusta" ayat-ayat Allah yang telah memberikan adanya isyarat kenabian Muhammad saw. ${ }^{1}$

\footnotetext{
${ }^{1}$ Muhammad Ali as-Shobuniy, Shafwatu al-Tafasir, Darel Hadits, Kairo, jilid 1 h. 368
} 
Allah SWT akan tetap agung selama-lama nya, sesiapa saja yang berniat menjatuhkan-Nya, dan merasa yakin dapat melakukannya, pada akhirnya mereka akan memusnahkan dan menghancurkan diri mereka sendiri, tanpa dapat mengurangi sedikit pun dari keaagungan Allah swt. Saat ini kita berada di zaman yang kritis, dan kemungkinan zaman yang penuh tantangan ini akan terus berlanjut, dan hanya Allah sajalah yang Maha mengetahui apa yang akan berlaku. Satu atau dua dasawarsa yang lalu kecenderungan ilmuan Barat memaksa kaum muslimin melenyapkan ayat-ayat yang berkaitan dengan orang-orang Yahudi. $^{2}$

Jean-Paul Satre penganut faham eksistensialis yang juga keturunan Yahudi berkata : "Akal mesti menggantikan agama, dan diharapkan sebagai penyelesai utama masalah-masalah kehidupan $^{3}$. Disisi lain pula, Karl Marx mengatakan : Orang Yahudi hanya dapat bebas manakala sifat ke Yahudiannya tidak lagi dipertahankan". 4

Bangsa Yahudi atau Bani Israil ini sebagaimana yang kita baca Al Qur'an adalah bangsa yang dahulunya dimanjakan dengan pelbagai limpahan nikmat dan karunia Allah (QS.Al Baqarah, 2:47), mereka juga diberikan hidangan yang istimewa iaitu, "manna was salwaa" (QS.Al Baqarah, 2:57), tetapi tetap saja mereka tidak pernah puas dengan nikmat-nikmat Allah tersebut. Mereka juga adalah bangsa yang sering diselamatkan Allah SWT, termasuk dari kedzaliman Fir'aun (QS.Al Baqarah, 2:49-50), dan masih banyak lagi karunia dan kenikmatan- kenikmatan lainnya yang Allah limpahkan kepada bani Israil ini, termasuk juga

\footnotetext{
${ }^{2}$ M.M al-Azhamiy, The History The Qur'anic Text, Gema Insani Press, 2005, h. 383

${ }^{3}$ Ibid, h. 373

${ }^{4}$ Ibid, 372
} 
mayoriti para nabi diutus kepada mereka dan banyak di antaranya yang dibunuh (QS. Ali Imran, 3:21).

Sikap kufur atau tidak taat terhadap aturan Allah akan senantiasa melekat pada bani Isra'il, sebagai contoh mereka diperintah menyembelih lembu betina, namun mereka tidak bersegera melaksanakan perintah tersebut, justeru mereka banyak bertanya mengenai esensi dan ciri-ciri lembu tersebut, dengan tujuan mengingkari perintah Allah sebagaimana dalam firman Allah surah Al Baqarah 67-71

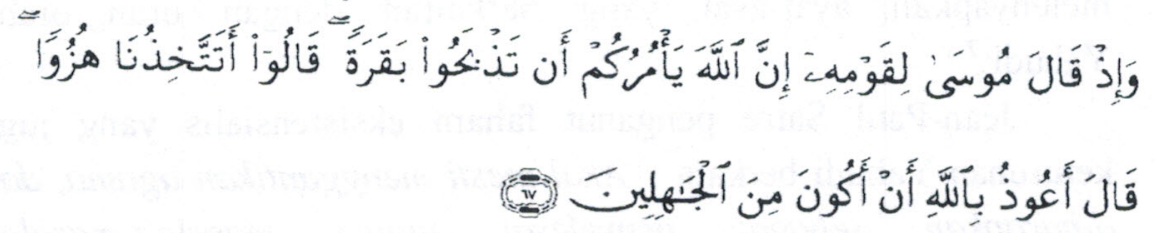

Maksudnya :

Dan (ingatlah), ketika Musa Berkata kepada kaumnya: "Sesungguhnya Allah menyuruh kamu menyembelih seekor lembu betina." mereka berkata: "Apakah kamu hendak menjadikan kami buah ejekan?" Musa menjawab: "Aku berlindung kepada Allah agar tidak menjadi salah seorang dari orang-orang vang jahil".

Ayat ini masih berbentuk uraian tentang bani Isra'il dengan aneka nikmat Allah yang dianugerahkan kepada mereka serta pelbagai kecaman atas sikap buruk mereka. Ayat sebelum ini adalah uraian tentang kederhakaan mereka menyangkut hak-hak Allah secara umum. Ayat ini menggambarkan kekerasan hati dan kedangkalan pengetahuan mereka tentang makna keberagamaan serta bagaimana seharusnya sikap mereka terhadap Allah dan NabiNya

\section{Narasi "Lembu Betina" dalam surat al-Baqarah}

Surat ini turun setelah nabi Muhammad saw hijrah ke Madinah. Ayat nya berjumlah 286 ayat, begitu banyak persoalan 
yang dibicarakannya, tidak hairan kerana masyarakat Madinah ketika itu plural dan heterogen, sama ada dalam suku, agama, mahupun kecenderungan lainnya. Disisi lain ayat-ayat surah ini berbicara menyangkut peristiwa-peristiwa yang terjadi pada masa yang cukup panjang.

Ayat-ayat didalam surah ini sebagian besar nya membicarakan tema-tema hukum syaricat, 'aqidah, 'ibadah, micamalat, akhlak, perkara-perkara nikah, thalaq, iddah, hukum puasa, hukum haji dan umrah, sifat-sifat orang mu'min, orang kafir, munafiqin, kemudian juga menceritakan tentang khalifah dan historikal kisah "bapak manusia" iaitu nabi Adam a.s. Surah ini membincangkan secara rinci tentang ahlul Kitab iaitu Bani Isra'il (Yahudi), kerana mereka adalah komuniti yang selalu berbuat sewenang-wenang (dzalim) kepada umat Islam di Madinah.

Surah ini dinamai al-Baqarah, kerana tema pokoknya menguraikan kisah al-Baqarah dengan bani Isra'il.Ada seseorang yang terbunuh dan tidak diketahui siapa pembunuhnya.Melalui kisah al-Baqarah inilah ditemukan bukti kebenaran dari petunjukpetunjuk Allah ${ }^{6}$.

Diantara kelebihan surat ini sebagaimana dijelaskan oleh beberapa hadith, seperti hadith yang diriwayatkan oleh Imam Muslim dan al-Tirmidzi : Janganlah kamu jadikan rumah-rumah kamu kuburan-kuburan, sesungguhnya syeitan akan lari dari rumah yang dibacakandidalamnya surah al-Baqarah. Riwayat lainnya adalah dari Imam Muslim, berkata Nabi saw :" bacalah surah al-Baqarah maka sesungguhnya membacanya adalah berkah, meninggalkannya adalah satu penyesalan, dan dengan

\footnotetext{
5 As-Shobuniy, op-cit h.29

${ }^{6}$ M.Quraish Shihab, Tafsir al-Mishbah, Lentera Hati,Jakarta, 2009, jilid 1 h. 101
} 
membacanya tidak akan sanggup kebatilan menngusainya, artinya adalah "sihir"?

Ayat-ayat ini berhubungan dengan ayat-ayat sebelumnya yang menjelaskan kejahatan-kejahatan kaum Yahudi, seperti melanggar perjanjian, melanggar peraturan Allah di hari sabtu, dan menolak mengamalkan Taurat.Jadi ayat-ayat ini masih melanjutkan penyebutan keburukan-keburukan mereka ${ }^{8}$. Abdurrahman bin Naasir as-Sa diy mengingatkan sebelum penguraian ayat ini, bahawa kebanyakan mufassir termotivasi dengan muatan kisạhkisah isra'iliyyat, meskipun terdapat nash yang membenarkannya, namun ada juga nash yang menegah periwayatan isra'iliyyat, dan tidak dibenarkan jika sekiranya kisah tersebut datang dengan riwayat-riwayat yang "majhul" 9 . Kisah ini merupakan satu dari ragam kisah-kisah yang di sebut dalam al-Qur'an, walaupun terdapat juga realiti lain dari cerita-cerita versi Israiliyat. Namun, penyebutannya dalam Alquran membuat kisah ini benar adanya, dan inilah kisah di balik surah kedua kitabullah tersebut.Ibnu Abi Hatim meriwayatkan dari Muhammad bin Sirrin dari 'Ubaid alSalmani yang menjadi latar belakang penyembelihan "lembu betina" ini, , ia berkata :

"Dikalangan Bani Isra'il terdapat seorang laki-laki yang mandul, tidak beranak, sementara dia memiliki harta kekayaan yang melimpah, maka anak saudaranyalah (keponakannya) sebagai pewarisnya.Kemudian dia dibunuh oleh keponakannya itu.Pada malam hari mayatnya dibawa dan diletakkannya didepan pintu salah satu dari mereka (bani Isra'il). Ketika pagi hari tiba, ia menuduh pemilik rumah dan masyarakat sekitar sebagai pembunuhnya,

\footnotetext{
${ }^{7}$ As-Shobuniy. Op-cit, h. 30

${ }^{8}$ Wahbah az-Zuhailiy, Tafsir al-Munir, Gema Insani, Jakarta, 2013, jilid 1 h. 146

${ }^{9}$ Abdurrahman bin Naasir as-Sa'diy, Tafsir Kalam al-Mannan, Resalah publisher, 2002, h.57
} 
sehingga mereka mengangkat senjata dan saling serang. Beberapa orang yang memiliki pikiran yang bijak berkata : "mengapa kalian saling membumh, padahal ada Rasul Allah ditengah-lengah kalian?", Merekapun mendatangi Musa a.s dan menceritakan peristiwa itu kepadanya. Musa pun berkata sebagaimana firman Allah ayat 67. ${ }^{\circ}$ Ubaid bin as-Salmani melanjutkan apa saja meskipun yang paling buruk, namun mereka mempersulit diri, maka Allah mempersulit mereka hingga mereka sampai pada lembu yang mereka diperintahkan menyembelihnya. Akhirnya mereka menemukan lembu itu pada seseorang yang tidak mempunyai lembu lain kecuali lembu betina itu. Si pemiliki lembu itu berkata :Demi Allah aku tidak akan melepaskan lembu itu jika harganya kurang dari emas sepenuh kulitnya".Maka merekapun menyembelihnya dan memukul mayat tadi dengan bagian tubuh lembu itu, maka bangunlah orang yang mati itu. Setelah itu mereka bertanya :" siapakah yang membunuhmu? Ia menjawab: "orang ini" sambil meminjuk kepada anak saudaranya tersebut. Kemudian diapun terkulai dan mati kembali.Maka keponakannya itu tidak diberi warisan sedikitpun dari kekayaannya. Sejak itulah seorang pembumuh tidak berhak mendapatkan warisan dari orang yang dibunuhnya". 10 Ayat ini memberikan ictibar kepada kita, bahawa hukum Allah tidak semua nya dapat dirasionalkan, jadi tidak wajar kita menentang dan melawannya.Perintah penyembelihan lembu betina menunjikan bahawa bani Israel masih sulit menghilangkan kenangan ketika mereka menyembah anak lembu. Allah swt memberitahukan tentang sikap keras kepala bani Isra'il dan banyaknya pertanyaan yang mereka ajukan kepada nabi Musa a.s.

1unu Katsir Abul Fida' Isma'il, 1419, Tafsir al-Qur'an al Azhiim, , Juz 1 h. 152 
Oleh itu ketika mereka mempersulit diri sendiri, maka Allah pun mempersulit mereka, seandainya mereka menyembelih lembu bagaimanapun keadaannya, maka itu sudah cukup baginya, sebagaimana yang dikatakan oleh Ibnu ${ }^{\mathrm{c}}$ Abbas r.a, 'Ubaidah, dan lainnya. Ibnu Jarir meriwayatkan dari Ibnu cAbbasr.a : "seandainya mereka menyembelih lembu yang paling buruk sekalipun, maka cukuplah bagi mereka, tetapi ternyata mereka mempersulit diri, sehingga Allah pun mempersulit mereka". Dalil ini bersanad sahih, juga diriwayatkan perawi lainnya dari Ibnu "Abbas

Syaikh Mutawalli Syacrawi, menjelaskan :" sebab suatu perintah hanya wajar dikemukakan jika perintah tersebut bersumber dari siapa yang setingkat dengan yang bertanya atau yang lebih tinggi kedudukannya, adapun jika perintah itu ditujukan kepada yang lebih rendah kedudukannya, tidaklah wajar bagi yang berkedudukan rendah untuk menanyakan latar belakang perintah itu, paling tidak sebelum perintah dilaksanakan. Berulang-ulang nabi Musa a.s menekankan bahawa apa yang diucapkannya adalah perintah Allah serta bersumber dari Nya. Disinilah letak rahasianya. Seandainya setiap orang yang diperintah bertanya kepada Allah apa rahasia perintah-Nya, ketika itu dia akan melaksanakan perintah itu disebabkan adanya rahasia yang melatar belakinya, bukan kerana Allah. Jika demikian tidak ada bezanya orang yang beriman dan yang tidak beriman.

Pendapat yang sama juga dikemukakan oleh ${ }^{\mathrm{c}}$ Ubaidah, ${ }^{c}$ Aliyah, dan 'ulama lainnya, artinya lembu tersebut tidak lembu tua dan tidak juga muda yang belum perneh dikahwini lembu jantan, sebagaimana yang dikatakan Abui "Aliyah, As-Suddi, dan Ibnu ${ }^{\mathrm{c}}$ Abbas. Ad-Dahhak dari Ibnu ${ }^{\mathrm{c}}$ Abbas, beliau mengataka mengenai

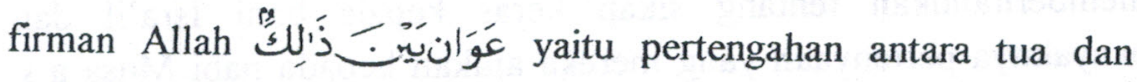
muda, dan itulah haiwan yang yang paling kuat dan bagus. 
Sedangkan al-Suddimengatakan : " iaitu antara yang sudah melahirkan dan cucu yang dilahirkan anaknya. Sementara itu Mujahid dan Wahab bin Munabbih :" lembu tersebut berwarna kuning", oleh itu Musa mempertegas "warna kuning lembu itu dengan menyebutkan sebagai kuning tua" 11

$\mathrm{Sa}^{c}$ id bin Jubairmengatakan : "warnanya benar-benar murni lagi jernih". Hal serupa juga diriwayatkan dari Abu "Aliyah, Rabicah, al-Suddi, Hasan Basri dan Qatadah. Dalam tafsirnya alAufi dari Ibnu "Abbas ra mengenai firman Allah mengatkan "karena sangat kuningnya, maka warnanya nyaris putih".

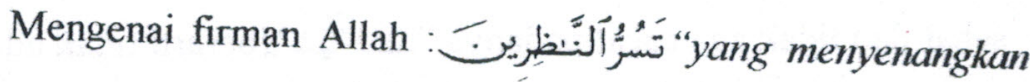
orang-orang melihatnya", al-Suddi mengatakan : "menakjubkan bagi orang yang menyaksikannya". Demikian pula Abul 'Aliya, Qatadah, dan Rabi' bin Anas. Sementara Wahab bin Munabbihmengatakan :"Jika engkau melihat kulitnya, maka terbayang dalam benakmu bahwa sinar matahari terpancar dari kulitnya."

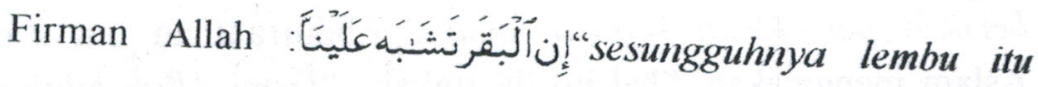
masih samar bagi kami" maksudnya karena ciri-cirinya terlalu banyak sehingga menjadikannya samar. Oleh itu sebutkan keistimewaan lembu itu dan juga sifat-sifat yang dimilikinya kepada kami. "dan Sesungguhnya kami, Insya Allah" jika engkau menjelaskannya kepada kami, "niscaya kami akan memperoleh petunjuk. Dalam satu riwayat nabi saw bersabda Seandainya mereka tidak mengucapkan Insya

${ }^{11}$ Ibnu Katsir, op-cit h. 154 
Allah, tentu ciri-ciri lembu itu selamanya tidak pernah akan menjadi jelas bagi mereka."

Nabi Musa a.s berkata :

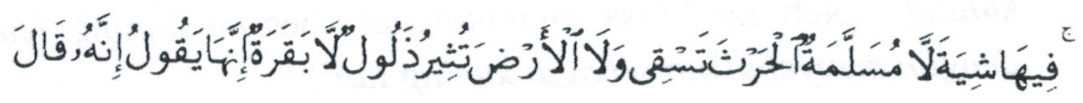

Maksudnya : "Allah berfirman lembu betina itu ialah lembu yang belum pernah dipakai mengolah tanah, tidak untuk mengairi tanaman". Artinya lembu betina itu tidak dihinakan dengan menggunakannya untuk bercocok tanam dan tidak juga untuk menyiram tanaman, tetapi lembu itu sangat dihormati, elok, mulus,

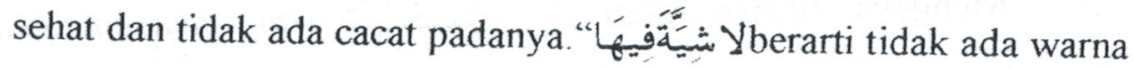
lain selain yang dimilikinya.

Sementara menurut Atha' al-Khurasani berarti warna lembu itu hanya satu iaitu polos. "mereka berkata:" sekarang barulah kamu menerangkan hakikat lembu betina yang sebenarnya".

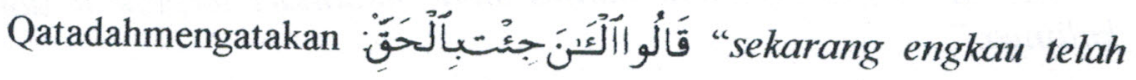
berikan penjelasan kepada kami". Abdurrahman bin Zaid bin Aslam mengatakan: "hal itu dikatakan : "Demi Allah telah datang kepada mereka kebenaran".

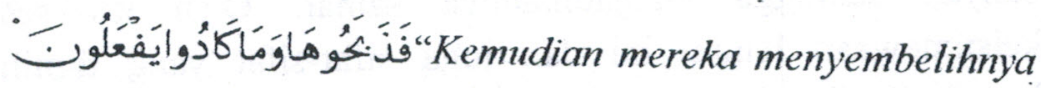
dan mereka nyaris tidak mengerjakannya". Dari Ibnu 'Abbas, AdDahhak mengatakan: " Mereka myaris tidak melakukannya.Penyembelihan itu bukanlah suatu yang mereka kehendaki, karena yang merka inginkan justeru tidak menyembelihnya".

Maksudnya, meskipun sudah ada semua penjelasan, juga berbagai tanya jawab, serta keterangan tersebut, namun mereka tidak menyembelihnya kecuali setelah bersusah payah mencarinya. 
Semua itu mengandung celaan terhadap mereka, kerana tujuan mereka melakukan hal itu tidak lain untuk menunjukkan kesombongan. Oleh itu mereka nyaris tidak menyembelihnya.

Ayat 72 surah al-Baqarahtermakna “kalian

berselisih" demikian dijelaskan Imam al-Bukhari, hal yang sama juga dikatakan oleh Mujahid. Sedangkan menurut Atha' alKhurasani dan ad-Dhahak mengartikan dengan "kalian saling bertengkar". Ibnu Abi Hatim menceritakan bahawa Shadaqah bin Rustum memberitahu kami bahwa dia pernah mendengar alMusayyab bin Raficmengatakan :"tidaklah seseorang berbuat kebaikan dalam tujuh bait, melainkan Allah akan memperlihatkannya". Dan tidaklah seseorang berbuat kejahatan dalam tujuh bait melainkan Allah Allah akan memperlihatkannya".

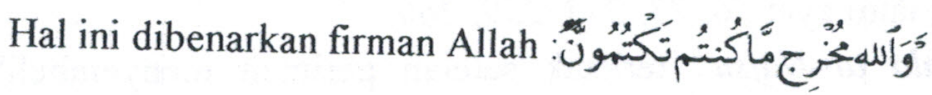

Ayatterang dimaksud dengan "satu bagian

disini adalah satu bagi dari tubuh lembu".Sehingga demikian mukjizat itu terwujud pada bagian tubuh lembu tersebut. Dan pada saat yang sama bagian tubuh itu telah ditentukan. Seandainya penentuan anggota tubuh ini bermanfaat bagi kita dalam urusan agama dan dunia, niscaya Allah akan menjelaskannya. Namun Allah menyamarkan nya dan tidak ada satupun riwayat yang sahih berasal dari Nabi yang menjelaskannya, maka kitapun menvamarkan hal itu sebagaimana Allah menyamarkannya ${ }^{12}$, kecuali interpretasi isra'iliyyat yang dikemukakan al-Tabariy dengan mendatangkan pelbagai pendapat berhubungan dengan anggota tubuh lembu yang digunakan untuk memukul si mati, ada

${ }^{12}$ Ibid, h. 157 
yang mengatakan anggota tubuh itu paha nya dan bagian antara dua bahu lembu dan ada juga yang menyatakan bahagian tulang lembu. ${ }^{13}$

كََّ

tersebut dengan bagian tubuh lembu betina itu, hingga akhirnya mayat tersebut hidup kembali".Dengan kejadian itu Allah memperlihatkan kekuasaan-Nya dan kemampuan-Nya untuk menghidupkan orang mati, seperti yang mereka saksikan dalam kes pembunuhan itu. Allah menjadikan peristiwa ini sebagai hujjah bagi mereka akan adanya tempat kembali (akhirat) sekaligus sebagai jalan keluar dari permusuhan dan pertikaian yang berlaku dikalangan mereka. Dalam surat ini Allah telah menyebutkan kekuasaan-Nya menghidupkan orang mati pada lima ayat dalam al-Baqarah, iaitu ayat 56, 73, 243, 259, 260.

"Qatala an-Nafsu" terletak setelah perintah menyembelih lembu, sesungguhnya tujuannya adalah untuk "al-Taswiq" atau dorongan untuk mengetahui sebab penyembelihan lembu, dan juga, dan untuk takrir (pengulangan) pada kecaman dan penghinaan. Abu Su'ud berkata : "dirobahnya susunan tersebut untuk takrir altowbikh dan menyebutkan kecaman"14. Ta'khir lafzhan wattaqdiim ma'nan (lafaz nya disebutkan belakangan, tetapi secara makna ia terjadi lebih dahulu), dan berfungsi untuk semakin meningkatkan rasa ingin tahu tentang sebab musabbab penyembelihan lembu betina itu ${ }^{15}$ “ kata أَ pada firman Allah ta'ala bermakna "bal" artinya "bahkan" lebih keras dari batu.

\footnotetext{
${ }^{13}$ Al-Tabariy, Jami'ul Bayan jilid $2: 229$ dalam Ahmad Nadjib bin Abdullah alQari, 2009,Isu Isra'iliyyat dan Hadits Palsu, Kelantan, h.44

${ }^{14}$ As-Shobuniy jilid 1 h. 68

${ }^{15}$ Wahbah az-Zuhailiy, op-cit h. 146
} 
Menurut Quraish Shihab ayat 72 merupakan latar belakang dari cerita yang dikemukakan sebelum ayat ini.Namun latar belakang cerita ini diletakkan dikemudian, mungkin disebabkan konteks kelompok ayat ini adalah gambaran tentang sikap batin dan keculasan orang-orang Yahudi.Sayyid Quthb berkomentar bahawa tabi'at Bani isra'il yang tercermin dalam ayat ini iaitu putusnya hubungan antara jiwa dengan sumber keimanan kepada yang ghaib, kepercayaan kepada Allah, membenarkan apa yang disampaikan Rasul Nya, bermalas-malasan dan menunda pemenuhan kewajiban sambil mencari alasan dan dalih, berolok-olok yang lahir dari kebejatan hati dan keburukan ucapan ${ }^{16}$.

Al-Biqacimenyatakan : "kisah lembu mempunyai dua sisi (dalam rangka menjelaskan nikamat ilahi), pertama, nikmat kema'afan atas sikap penundaan pelaksanaan perintah Allah. Kedua, nikmat penjelasan tentang siapa pembunuhnya.Dan mereka juga dikecam dengan dua kecaman, pertama, sikap tidak sopan dalam tuduh-menuduh dan pelecehan serta menunda-nunda pelaksanaan perintah Allah, kedua, pembunuhan yang berlaku.Kalau ayat ini disusun sesuai jalan kisah, tujuan tersebut tidak tercapai.Karena itu didahulukan kisah lembu yang sejalan juga dengan kisah pelanggaran dihari sabtu.

Muhammad "Ali as-Shobuniy menyimpulkan bahawa. :" memperolok-olok dalam urusan agama yang diperkatakan Bani Isra'il kepada nabi Musa a.s adalah kebodohon dan pelanggaran sangat besar yang dilakukan Bani Isra'il ${ }^{17}$. Sementara itu ${ }^{\mathrm{c}}$ Abdurrahman bin Naasir as-Sac diy mengatakan : "orang bodoh adalah orang yang berbicara dengan satu perkataan yang tidak memiliki faedah, dan suka memperolok-olok orang lain. ${ }^{18}$

\footnotetext{
${ }^{16}$ M.Quraish Shihab, op-cit h.272

${ }^{17} \mathrm{M}$. Ali as-Shobuniy, op-cit 69

${ }^{18}$ Abdurrahman bin Naasir as-Sa'diy, op-cit h. 55
} 
Ayat 74 ini sebagai celaan dan kecaman terhadap bani Isra'il atas sikap rinereka setelah menyaksikan tanda-tanda kekuasaan Allah dan kemampuan-Nya menghidupkan orang yang sudah mati. "setelah ituhatimu menjadi keras" iaitu seluruhnya, "seperti batu" yang tidak akan pernah menjadi lunak selamanya. Oleh itu Allah melarang orang-orang beriman menyerupai keadaan mereka sebagaimana firman Allah QS al-Hadid 16:

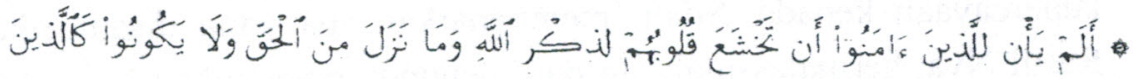

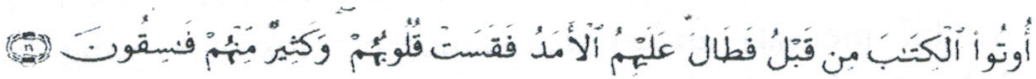

Maksudnya :

Belumkah datang waktunya bagi orang-orang yang beriman, untuk tunduk hati mereka mengingat Allah dan kepada kebenaran yang Telah turun (kepada mereka), dan janganlah mereka seperti orang-orang yang sebelumnya Telah diturunkan Al Kitab kepadanya, Kemudian berlalulah masa yang panjang atas mereka lalu hati mereka menjadi keras. dan kebanyakan di antara mereka adalah orang-orang yang fasik.

Dalam ayat lain (Al-Ahzab ayat 69) Allah juga tegaskan :

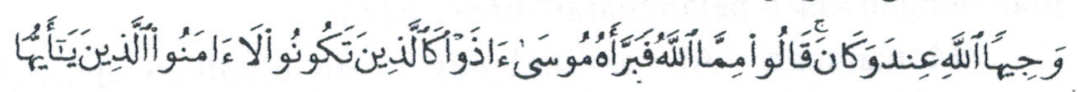

Maksudnya :

Hai orang-orang yang beriman, janganlah kamu menjadi seperti orang-orang yang menyakiti Musa; Maka Allah membersihkannya dari tuduhan-tuduhan yang mereka katakan.dan adalah dia seorang yang mempunyai kedudukan terhormat di sisi Allah.

Dari huraian ayat diatas sesungguhnya menjadi jelas bagi kita bahawa mencontoh dan menjadikan sifat dan karakter kita serupa dengan sifat dan karakter bani Isra'il adalah terlarang dan mesti 
kita hindari, ditambah lagi sebutan "fasik" juga telah melekat kepada bani Isra'il sebagaimana pada ayat diatas. Bahkan ${ }^{c}$ Abdullah ibnu 'Umar (putera Umar bin Khattab) mengatakan bahawa Yahudi dan Nasrani adalah golongan "musyrik", beliau mengatakan :" saya tak pernah tahu syirik yang lebih parah dari wanita yang mengatakan Tuhannya Isya atau manusia lainnya", lebih dari itu "Umar pun pernah marah kepada dua sahabatnya Thalhah dan Huzaifah yang mengahwini wanita ahlul Kitab, yang kemudian keduanya (sahabat tersebut) menceraikan wanita itu ${ }^{19}$. Begitu juga dengan sebutan "kafir" juga Allah lekatkan kepada bangsa Yahudi ${ }^{20}$, sikap jahat mereka kepada para nabi, termasuk kepada nabi Muhammad saw, karena setelah datangnya pengetahuan dan penjelasan kepada mereka yang terdapat didalam kitab-kitab suci mereka, mereka membunuh nabi Zakariya a.s dan Yahya a.s tanpa ada sesuatu yang menimbulkan kecurigaan terhadap para nabi yang mereka bunuh tersebut. Mereka membunuh nabi dikarenakan para nabi tersebut adalah karena mereka menyerukan untuk mentauhidkan ALLAH dan menyampaikan rislah. Bangsa Yahudi terkenal sebagai bangsa pembunuh para nabi, orang-orang saleh dan para ulama'21.

Dalam tafsirnya Ibnu ${ }^{c}$ Abbas r.a, dan al-Aufimengatakan : "ketika orang yang terbumuh itu dipukul dengan sebagian dari anggota tubuh lembu betina, maka ia duduk dalam keadaan hidup, tidak pernah ia seperti itu sebelumnya". Lalu ditanyakan

${ }^{19}$ M. Ali As-Shobuniy, Tafsir ayat ahkam, Maktab al-Ghazali, Damaskus, Syiria, jilid 1
h.28,

${ }^{20}$ Lihat Q.S Ali Imran ayat 21 :

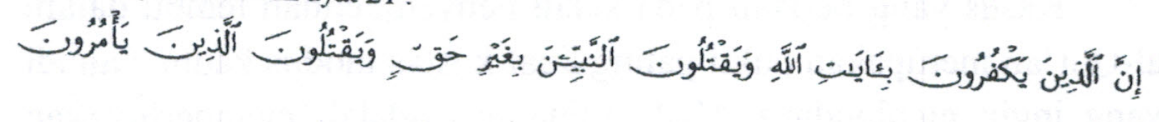

${ }^{21}$ Wahbah al-Zuhailiy, op-cit jilid 2, h.218

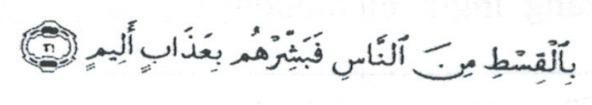


kepadanya :siapakah yang telah membumuhmu? Ia menjawab anak-anak saudaraku yang telah membunuhku. Setelah itu, nyawanya dicabut kembali. Ketika Allah mencabut nyawa orang itu, maka anak-anak saudaranya itu berujar :"Demi Allah, kami tidak membumuhnya". Demikianlah mereka mendustakan kebenaran setelah mereka menyaksikannya sendiri".

Allahpun berfirman "setelah itu hatimu menjadi keras" yaitu anak-anak saudara orang tersebut, "seperti batu atau hahkan lebih keras lagi". Akhirnya hati Bani Isra'il seiring berjalannya waktu menjadi keras tidak mahu mengenal pelajaran, setelah mereka menyaksikan sendiri tanda-tanda kekuasaaan Allah dan mukjizatNya.Sifat keras hati mereka itu seperti batu yang tidak dapat lagi dilunakkan, atau bahkan lebih keras dari batu.Kerana celah-celah batu masih boleh memancarkan mata air yang mengaliri sungaisungai. Adapula diantara batu-batu tersebut yang terbelah sehingga keluarlah air darinya meski tidak dapat mengalir.Ada juga yang meluncur jatuh dari puncak gunung karena takut kepada Allah, dan masing-masing memiliki rasa takut seperti itu sesuai dengan kodratnya ${ }^{22}$. Barangkali kerasnya hati mereka ini disebabkan oleh terkurungnya mereka dalam ruang kekufuran dan kedurhakaan, dan cinta dunia.

\section{Dimensi Fiqah sosial kemasyarakatan dari Narasi "Baqarah"}

Al-Qur'an telah membezakan antara orang saleh dengan orang-orang derhaka, Al-Qur'an juga memberikan penilaian yang objektif dengan nilai baik dan buruk kepada masing-masingnya sesuai dengan sifat dan perilaku yang mereka miliki.

Kasus yang berlaku pada kisah penyembelihan lembu dalam al-Qur'an merupakan bukti paling kuat keatas modus kaum Yahudi yang ingin menipudaya Allah, tujuannya adalah memperlihatkan

${ }^{22}$ Ibnu Katsir, op-cit h.159 
bahawa Rasul adalah orang yang tidak mampu membantah mereka sehingga umatnya ragu terhadap kebenaran kenabiannya Musa a.s dan keluar dari agama beliau.

Kaum Yahudi memperlihatkan keimanan mereka dalam satu keadaan, kemudian setelah itu kembali lagi kepada kekufuran. Sehingga ketika orang-orang telah merasa aman dengan nya mereka perlihatkan kekufuran mereka kembali kepada keyahudiannya sehingga orang yang baru masuk Islam atau yang masih iman nya lemah menganggap mereka itu benar, dan orang Islam yang masih lemah Imannya akan menjadi ragu kepada Islam. ${ }^{23}$. Al-Qur'an telah menceritakan kepada kita tentang kejahatan mereka ini dibanyak ayat nya, sebagaimana ayat 76 surat al-Baqarah :

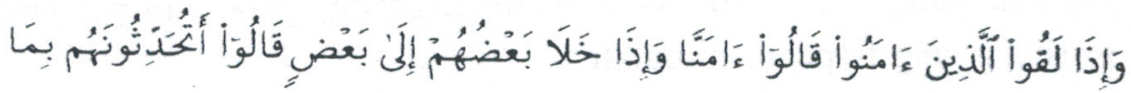

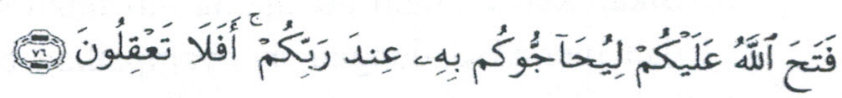

Maksudnya :

Dan apabila mereka berjumpa dengan orang-orang yang beriman, mereka berkata:" kamipun Telah beriman," tetapi apabila mereka berada sesama mereka saja, lalu mereka berkata: "Apakah kamu menceritakan kepada mereka (orang-orang mukmin) apa yang Telah diterangkan Allah kepadamu, supaya dengan demikian mereka dapat mengalahkan hujjahmu di hadapan Tuhanmu; tidakkah kamu mengerti?"

Dan surat ${ }^{\mathrm{C}}$ Ali Imran ayat 72 :

\footnotetext{
${ }^{23}$ Nasywah Ulwaniy, Yahudi dan Kerusakan di Bumi, 2007, Akademika Presindo, Jakarta, h. 223
} 


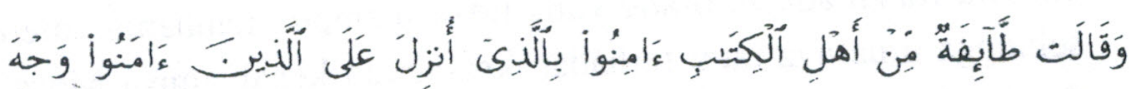

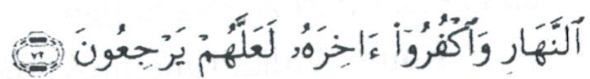

Maksudnya :

Segolongan (lain) dari ahli Kitab Berkata (kepada sesamanya): "Perlihatkanlah (seolah-olah) kamu beriman kepada apa yang diturunkan kepada orang-orang beriman (sahabat-sahabat rasul) pada permulaan siang dan ingkarilah ia pada akhirnya, supaya mireka (orang-orang mukmin) kembali (kepada kekafiran).

Ada banyak pelajaran yang dapat dipetik dari kisah ini yang menjelaskan sebahagian keburukan kaum Yahudi serta pendirian mereka yang keras dan suka membangkang, pelajaran-pelajaran tersebut yang terpenting adalah :

1. Sikap keras dalam beragama bukanlah sikap yang terpuji, dan memaksa dengan menyampaikan banyak pertanyaan bukanlah perbuatan yang dikehendaki. Oleh itu Allah Ta'ala melarang kita berbuat begitu pada waktu turunnya al-Qur'an, Dia berfirman : "Hai orang-orang yang beriman, janganlah kamu menanyakan (kepada nabimu) hal-hal yang jika diterangkan kepadamu, niscaya menyusahkan kamu (al-Macidah ayat 101). Kategori pertanyaan yang dilarang itu adalah perkara yang disembunyikan Allah swt dari hamba-Nya, contohnya tentang Hari Kiamat, hakikat ruh, rahasia Qadha Qadar, juga pertanyaan yang diajukan untuk membingungkan, main-main dan mengejek, pertanyaan untuk menunjukkan pembangkangan, pertanyaan-pertanyaan "aghaaliith" (masalah-masalah yang sukar yang diajukan kepada ulama agar ia keliru menjawab sehingga timbul fitnah, pertanyaan tentang hukum halal dan haram yang di 
diamkan syari;at. Allah telah mencatat ke buku Yahudi tentang dosa mengajukan pertanyaan secara mengejek, membantah, membangkang, mengingkari kebenaran yang telah nyata Sebagaimana Hadits Nabi saw berikut ${ }^{24}$ :

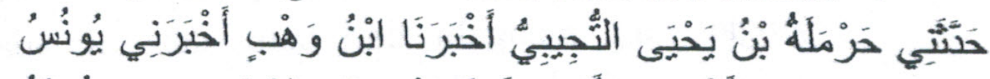

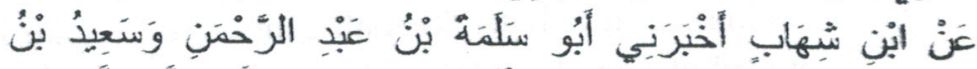

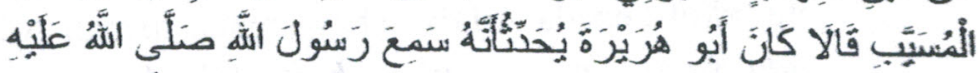

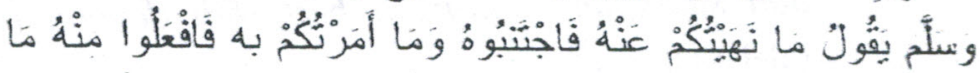

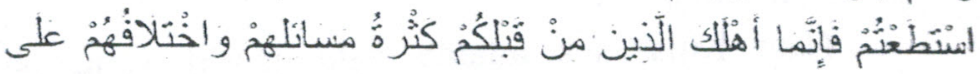

Maksudnya :"Jauhilah perkara yang kularang, dan laksanakanlah sebisa kalian perkara yang kuperintahkan. Banyak pertanyaan dan menentang para nabi telahg menyebabkan kaum sebelum kalian binasa".

2. Perintah untuk menyembah lembu betina, dan bukan haiwan lainnya, alasannya karena lembu betina ini sama jenisnya dengan haiwan yang pernah mereka sembah, iaitu c ijl (anak lembu) agar mereka tidak mengagungkan hewan tersebut

3. Olok-olok mereka terhadap perintah para Nabi Musa a.s menyebabkan mereka mendapat celaan dan hukuman.

4. Proses penghidupan orang yang terbunuh dengan cara membunuh makhluk yang hidup menunjukkan dengan sangat jelas kodrat Allah Ta'ala dalam menciptakan sesuatu dari lawannya.

5. Kecaman keras atas pembunuhan jiwa yang tidak bersalah.

${ }^{24}$ Muslim, Kitab Fadhaail Bab 14 
6. Tidak ada yang lebih buruk dan lebih aneh dari pernyataan bahawa batu lebih bermanfaat dàripada hati kaum Yahudi, sebab air dapat memancar dari batu itu. Mujahid berkata : tak ada batu yang jatuh dari puncak gunung, tak ada sungai yang mengalir dari batu, dan tak ada air yang memancar dari batu, kecuali semua itu berlaku kerana batu itu takut kepada Allah, sebagaimana firman Allah : "tidak ada suatupun melainkan bertashih dengan memuji-Nya (al-Israa: 44) ${ }^{25}$

Nabi Musa a.s adalah nabi Isra'il yang paling besar pengaruhnya, namun beliau selalu menerima realiti bangsa Yahudi yang tak tahu berterima kasih kepada Tuhan dan kepadanya.Sangat disayangkan bahwa leluhur Isra'il bukanlah contoh yang baik, mereka melakukan kecurangan dengan sanak keluarganya dan familinya sendiri.Mereka telah diperlihatkan berbagai mukjizat, berupa wabah, pembelahan laut, dia hanya meninggalkan selama empat puluh hari saja sudah membuat patung anak lembu emas untuk disembah.Perilaku semacam ini memunculkan keraguan yang serius tentang ketaatan bangsaYahudi memelihara ajaran ajaran Musa semasa hidupnya, apalagi setelah masanya.

Yahudi di zaman kita sekarang adalah Yahudi setiap masa dimana perbuatannya suka merosak, sewenang-wenang kepada umat Islam, seperti yang berlaku di Palestina, dengan dukungan negara-negara kafir melalui bantuannya yang beraneka ragam. Tugas kita adalah melenyapkan faktor-faktor perselisihan antara kita, dan meneguhkan agama Allah di muka bumi ini dengan bersatu menyusun kekuatan, ikhlas dalam beribadah dan beramal, saat itulah pertolongan Allah akan datang kepada kita sebagai mukmin, sebagaimana firman Allah :

${ }^{25}$ Wahbah az-Zuhailiy, op-cit h. 150 


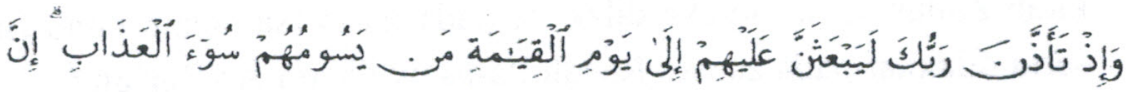

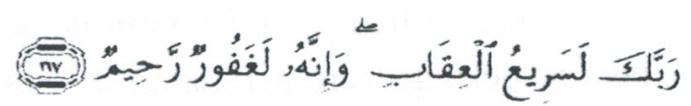

Maksudnya :

Dan (ingatlah), ketika Tuhanmu memberitahukan, bahwa Sesungguhnya dia akan mengirim kepada mereka (orangorang Yahudi) sampai hari kiamat orang-orang yang akan menimpakan kepada mereka azab yang seburuk-buruknya. Sesungguhnya Tuhanmu amat cepat siksa-Nya, dan Sesungguhnya dia adalah Maha Pengampun lagi Maha Penyayang.

Firman Allah ini berisi pernyataan bahawa azab akan berlanjut bagi mereka sampai hari kiamat. Siksaan dan penderitaan yang dialami oleh orang-orang Palestina dewasa ini begitu juga yang menimpa mereka di selatan Libanon dimana mereka diusir dan dikeluarkan dari tanahnya namun gagal atas rencanya adalah bukti terkuat atas hal itu. Kemenangan bagi sisa tanah air Islam niscaya akan didapat dan orang-orang Yahudi akan kehilangan tempat tinggal ${ }^{26}$, Allah swt berfirman :

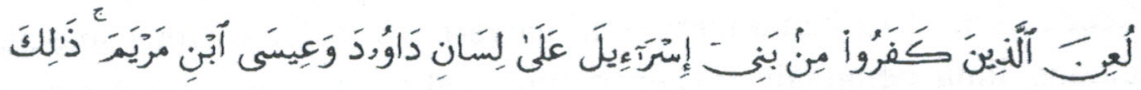

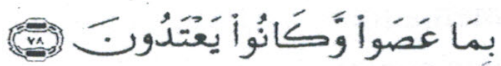

Maksudnya : Telah dila'nati orang-orang kafir dari Bani Israil dengan lisan Daud dan Isa putera Maryam. yang demikian itu, disebabkan mereka duriaka dan selalu melampaui batas.

Ibnu Abbas r.a berkata : mereka dilaknat melalui lisan pada zaman Nabi Musa dalam kitab Taurat dan pada masa Daud dalam

${ }^{26}$ Nasywah Ulwani, op-cit 267 
kitab Zabur, juga mereka dilaknat pada masa Isa dalam kitab Injil, serta dilaknat pada zaman Rasulullah saw dalam Al-Qur'an. ${ }^{27}$

Sejarah bani Isra'il penuh dengan kemaksiatan dan berbagai bentuk pelanggaran, perbuatan ini bukan kerja perseorangan tetapi merupakan unervesalisasi tabi'at Bani Isra'il.Dan suatu umat apabila sudah sampai pada tahap seperti ini dimana kemaksiyatan telah merajalela dikalangna orang-orang besar dan orang kecil dan tidak ada orang yang berusaha mencegahnya baik dengan tangannya mahupun dengan lidahnya atau dengan hatinya, maka nasib mereka akan hancur dan akan mendapat siksa di dunia dan akhirat.

\section{Kesimpulan}

Yahudi menjadi kuat karena lemahnya kita, karena kita sudah tidak layak lagi dibela oleh Allah. Kenapa kita tidak dibela oleh Allah?Karena banyak di antara kita sudah meninggalkan ajaran Allah. Jika kita sudah banyak meninggalkan ajaran Allah, maka kita tidak punya hak dibela lagi oleh Allah dan Allah akan biarkan siapa yang kuat dialah yang menang. Pada penghujung ayat 120 surah Al Baqarah, Allah SWT memberikan peringatan keras kepada kita, Jika kamu mengikuti hawa-hawa nafsu mereka setelah datang ilmu pengetahuan kepadamu, maka tidak ada hak bagimu menjadikan Allah sebagai pelindung dan penolong bagimu". Peringatan keras ini hendaknya menjadikan diri kita senantiasa berhati-hati atau waspada dalam mengarungi kehidupan ini, khususnya dalam menghadapi segala tipu daya Yabudi dan Nashara yang akan mengajak kita ke arah kecenderungan hawa-hawa nafsu mereka sehingga kita menjadi orang yang rugi.

${ }^{27}$ Tafsir al-Thabariy jilid 6 h.317. dan Mufradat al-Qur'an, Ar-Raghib alAsfahaniy h.451 
Setiap kali mereka membuat kerosakan, pada saat itu juga akan binasa. Hal ini merujuk pada firman Allah SWT: "Dan telah Kami tetapkan terhadap Bani Israil dalam Kitab itu: "Sesungguhnya kamu akan berbuat kerusakan di muka bumi ini dua kali dan pasti kamu akan menyombongkan diri dengan kesombongan yang hesar". Maka apabila datang saat hukuman bagi (kejahatan) pertama dari kedua (kejahatan) itu, Kami datangkan kepadamu hamba-hamba Kami yang mempunyai kekuatan yang besar, lalı mereka merajalela di kampungkampung, dan itulah ketetapan yang pasti terlaksana.Kemudian Kami berikan kepadamu giliran untuk mengalahkan mereka kembali dan Kami membantumu dengan harta dan anak-anak dan Kami jadikan kamu kelompok yang lebih besar"(QS.Al-Israa', 17:4-6).

Sikap selalu kufur inilah yang menyebabkan turunnya laknat Allah terhadap mereka. Allah SWT berfirman: "Telah dilaknat orang-orang kafir dari Bani Israil dengan lisan Daud dan Isa putera Maryam. Demikian itu disebabkan mereka durhaka dan melampaui batas.Adalah mereka tidak saling melarang dari kemungkaran yang mereka selalu perbuat Sungguh amat buruklah apa yang mereka perbuat itu" (QS. Al Maaidah, 5:78-79). Mereka telah pula dilaknat Allah menjadi kera yang hina (QS. Al Baqarah, 2:65), bahkan di samping karena ada pula yang dilaknat menjadi babi, "Katakanlah, "Apakah akan kuberitahukan kepada kamu hal yang lebih buruk balasannya dari itu di sisi Allah ?Yaitu orangorang yang dilaknat Allah dan dimurkai-Nya, dan di antara mereka Dia jadikan kera-kerc, babi-babi, dan (orang yang) menyembah berhala.Mereka itu amat buruk tempatnya dan lebih sesat dari jalan yang benar" (QS. Al Maaidah, 5:60). 


\section{DAFTAR KEPUSTAKAAN}

Al-Qur'anul Karim

Muhammad Ali as-Shobuniy, 1976, Shafwatu al-Tafasir, Darel Hadits, Kairo

M.M al-Azhamiy, The History The Qur'anic Text, Gema Insani Press, 2005

M.Quraish Shihab, Tafsir al-Mishbah, Lentera Hati,Jakarta, 2009

Nasywah Ulwaniy, Yahudi datı Kerusukum di Bumi, 2007. Akademika Presindo, Jakarta

Ar-Raghib al-Asfahaniy Abu al-Qasim al-Husain ibnu alMufaddal, 1997 , Mufradat al-Qur'an, Beirut, Darel Kutub al-Ilmiyyah

M. Ali As-Shobuniy, Tafsir ayat ahkam, Maktab al-Ghazali, Damaskus, Syiria

Ibnu Katsir Abul Fida' Isma'il, 1419, , Tafsir al-Qur'an al Azhiim,Beirut, Darel Fikri al-Arabiy

Abdurrahman bin Naasir as-Sa'diy, Tafsir Kalam al-Mannan, Resalah publisher, 2002,

Wahbah az-Zuhailiy, Tafsir al-Munir, Gema Insani, Jakarta, 2013, 